THEMATIC ARTICLES

ARTYKUŁY TEMATYCZNE

EETP Vol. 16, 2021, №. 3(61)

ISSN 1896-2327 / e-ISSN 2353-7787

DOI: $10.35765 /$ eetp.2021.1661.02

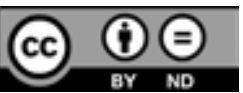

Submitted: 3.05 .2021

Accepted: 21.07 .2021

Suggested citation: Bilewicz-Kuźnia B. (2021). Inspiring children's mathematical activity through contact with a picture book, "Elementary Education in Theory and Practice", vol. 16, no. 3(61), pp. 27-41. DOI: 10.35765/eetp.2021.1661.02

Barbara Bilewicz-Kuźnia

ORCID: 0000-0003-1333-095X

Maria Curie-Skłodowska University in Lublin

\title{
Inspiring Children's Mathematical Activity Through Contact With a Picture Book
}

\author{
Wyzwalanie aktywności matematycznej dzieci \\ poprzez kontakt z ksiqż̇ka obrazkowa
}

\begin{abstract}
KEYWORDS ABSTRACT
picture book, Children's literature has a cognitive value and is a source of aesthetic mathematical experiences. Picture books with mathematical content are a special narration, children, type of children's books. The study aims to show that picture books mathematical where mathematical text is combined with images in an aesthetic activity, kindergarten form provide impulses to create educational situations that inspire mathematical activity. Based on the classification of mathematical activity by Ewa Kozak-Czyżewska, we developed our methodological proposals for stimulating creative and imitative mathematical activity in children. These suggestions are presented on the basis of our work with two books: Numbers written by Jacek Cygan and At our house written by Isabel Minhós Martins and Madalena Matoso. For the purpose of this study, educational classes with the use of mathematical literary texts were conducted for six-year-old children in kindergarten. It has been shown that picture books can inspire creative and imitative mathematical activity in children. By providing positive experiences, these texts can support the processes of learning mathematics, awaken children's motivation to calculate and use mathematics in everyday life. The presented study may be used as a model of working with picture books with mathematical content in kindergarten.
\end{abstract}




\section{SŁOWA KLUCZE ABSTRAKT}

książka obrazkowa, narracja matematyczna, dzieci, aktywność matematyczna, przedszkole
Literatura dla dzieci ma wartość poznawczą i jest źródłem przeżyć estetycznych. Jej szczególnym rodzajem są książki obrazkowe z wątkami matematycznymi. Celem opracowania jest ukazanie, że książki obrazkowe, rozumiane jako te, w których tekst matematyczny łączy się z obrazem w estetyczną formę, dostarczają impulsów do kreowania sytuacji edukacyjnych wyzwalających aktywność matematyczną. Opierając się na klasyfikacji aktywności matematycznej w opracowaniu Ewy Kozak-Czyżewskiej, opracowano własne propozycje metodyczne pobudzania twórczej i odtwórczej aktywności matematycznej dzieci, co ukazano na przykładzie pracy z książkami: Cyferki (autor: Jacek Cygan) i W naszym domu jest (autorzy: Isabel Minhós Martins, Madalena Matoso). Zajęcia dydaktyczne z wykorzystaniem matematycznych tekstów literackich przeprowadzono dla dzieci sześcioletnich w przedszkolu. Wykazano, że książki obrazkowe mogą być inspiracją w wyzwalaniu twórczej i odtwórczej aktywności matematycznej. Poprzez dostarczanie pozytywnych przeżyć mogą wspierać procesy uczenia się matematyki, rozbudzać dziecięcą motywację do liczenia i używania matematyki w życiu codziennym. Opracowanie może stanowić model pracy z książką obrazkową z wątkami matematycznymi w przedszkolu.

\section{Introduction}

The spoken and written word have long been used for didactics and educational interaction, especially in kindergarten. Children's literature is a source of aesthetic experiences and rich language, it stimulates thinking, acting, learning in motion, and artistic creativity. A special type of children's literature contains mathematical content, also called a mathematical narrative. It comes in various forms such as poems, stories, fairy tales for children and about children, or texts created by children.

The article aims to show the possibility of using picture books with mathematical content to stimulate mathematical activity in children. The methodology described in this study refers to the research showing direct evidence for the motivational and activating benefits of providing children with a narrative in learning mathematics. Researchers in the field have shown that picture books and fairy tales are excellent materials for developing mathematical abilities (Ross, Dryden 2009) and mathematical cognition in children (Van den Heuvel-Panhuizen, Van den Boogard 2008). The process of learning with the use of picture books is more effective than the process of learning without them because the stories presented in the texts are meaningful to children. The story is the basic means of building meaning (Van den Heuvel-Panhuizen, Elia, Robitzsh 2016: 324). The stimulating influence of books and narratives can also be found in the use of narration in learning science, i.e., in STEM education 
(Rostek 2019), effectively supporting the development of spatial thinking, especially spatial imagination, and the ability to perform mental rotations (Hong 1996; Jennings et al. 1992; Young-Loveridge 2004; Casey et al. 2002; Van den Heuvel-Panhuizen, Elia, Robitzsh 2015). In addition, it has been shown that the visual-spatial modeling of literary texts and stories helps children to understand the content and sequence of events in the story (actions) and to determine the relationship between characters, which is important when children solve mathematical problems (Dolya 2007: 82).

The main purpose of this study is to describe the possibility of using picture books and texts with math content in early education regarding triggering mathematical activity in children. The main research question is to what extent picture books and counting books with narrative poetry can be useful in mathematically activating children. The method of the study is a review and interpretation of children's literature with the aim to show the possibility of using mathematical books in preschool and early school practice.

\section{A Mathematical Picture Book}

The definition of a picture book in this study is taken from Van den Heuvel-Panhuizen, Elia, and Robitzsh (2016: 323). A picture book is understood as a book consisting of a text and illustrations "in which the story depends on the interaction between the written text and the image and where both have been created with the conscious aesthetic intention" (Arizpe, Styles 2003: 22). And while it might seem that reading picture books is not the best way to teach maths, the stories told in the books may contain mathematical content, so children have a chance to interact with mathematics. According to Van den Heuvel-Panhuizen, Elia, and Robitzsh (2016: 324), mathematical concepts children encounter in picture books must be broad. The book may be about numbers, measures, or geometry but also such issues as visible regularities, the pursuit of truth, and the search for causes, since they are all related to mathematics. A number of cognitive scientists consider "the story as a most natural package of organized knowledge in the cognitive system for acquiring and retaining information" (Casey, Andrews 2008: 276), and picture books can offer cognitive hooks to explore and construct mathematical concepts and skills (Van den Heuvel-Panhuizen, Elia, Robitzsh 2016: 324).

Among the respected Polish authors of texts with mathematical content are Jan Brzechwa (e.g., A week, Caterpillar, 7-mile shoes), Danuta Wawilow (Listen to a new, rectangular and square fairy tale, Triangle Karolina, Triangle fairy tale: a fairy tale about 100 kings of Lules) Wanda Chotomska (the poem Ten snowmen), Małgorzata Strzałkowska (poems Week and Calendar), Anna Łada-Grodzicka (a collection 
entitled: ABC of counting: Mathematical poems), Jacek Cygan (Numbers). New books also appear on the global market, published and translated into many languages, for example: The war of the Numbers by Darien Juan, At our house by Isabel Minhós Martins and Madalena Matoso, and One hundred seeds that flew away by Isabel Minhós Martins and Yary Kono. Many kindergartens also conduct didactic projects using and creating new, mathematical poetry for children (initiatives such as Mathematics in poems ${ }^{1}$ and Maths poems ${ }^{2}$.

\section{Mathematical Activity}

Activity is the primary learning mechanism. Activity allows humans to regulate their relations with the environment, realize goals and aspirations, and reveal their abilities. According to Jan Strelau (1992: 65), activity is a temperamental trait that manifests itself in the number and scope of actions taken by an individual with a specific stimulating value. It is always based on a specific willingness to act, which is triggered by internal factors such as needs, and external factors such as tasks. The source of activity, apart from the human factor, is the material world, its phenomena, objects and tools. A child can learn about the world using sensory-experimental or mathematical-logical methods. In the first case, the learning material comprises colors, shapes, smells, tastes and sounds; in the second it comprises words and their meaning. For this reason, the written word can also provoke activity, and more specifically, mathematical activity.

"Mathematical activity is aimed at shaping mathematical concepts and reasoning, stimulated by abstract problems or theoretical problems concerning specific situations" (Filip, Rams 2000: 34). Gustaw Treliński (2005) describes students' mathematical activity as the entirety of their activity related to the formation of mathematical concepts and reasoning, stimulated by various situations and actions. It may include:

1. concrete activities aimed at creating or researching concepts and reasoning,

2. mental activities (imaginary and abstract) aimed at:

a) creating concepts, researching them or using them,

b) reasoning and shaping reasoning,

c) formulating and solving theoretical and practical problems.

Activity manifests itself as external or internal actions. Thus, if someone does not do mathematical activities physically, it does not mean that they are not mathematically active. Ewa Kozak-Czyżewska (2008: 146) systematizes mathematical activity

1 https://p118.przedszkola.net.pl/aktualnosci/konkurs-matematyka-w-wierszykach.html (accessed: 15.03.3021).

2 https://psloneczko.szkolnastrona.pl/art,3038,4-wierszyki-matematyczne (accessed: 15.03.3021). 
distinguishing its eighteen forms according to the type of operation influencing the type of activity (creative or imitative activity), the nature of the performed activities (manipulative and motor; verbal, manifested as audible or quiet speech; and cognitive), and the type of material constituting the basis of the performed activity (tangible, graphic, symbolic). This classification can be used as a framework for proposing methodological activities for children using texts with mathematical content.

\section{Implications for Practice}

The methodological suggestions for practice presented below were implemented in 2020 during classes with a kindergarten group of about 20 six-year-old children in a public kindergarten. ${ }^{3}$ The classes were conducted by the author of the present study. Pedagogy students were also involved in the project to assist in didactic interventions. Many texts and books for children were used in the course of mathematics classes, two of which have been selected as methodological examples in this study: Numbers by Jacek Cygan and At our house by Isabel Minhós Martins and Madalena Matoso. Numbers ${ }^{4}$ is written in Polish, while At our house has been published in Polish, English and Spanish. Each text was first presented to the children as a picture book to look at, then a story to listen to, and finally as an inspiration for mathematical activities proposed by the teacher.

\section{Numbers in Motion: Experiencing and Taking Action on the Basis of the Numbers Picture Book}

The content of Numbers by Jacek Cygan (2011) is presented below to help the readers understand the essence of the text-inspired activities better.

Digits, one after another, were standing in a line, because the post office window was closed for an hour. The first was One, thin like a straw. Behind her was Two, a curve and a dash. Behind Two stood Three, two semi-circles. One, two, three, one, two, three. I can count already. How about you? Wiggle, wiggle, pretty line. Behind Three, Four, a chair upside down. And then Five, a noble digit but unlike anything else. Although a famous locksmith recently instructed me that two fives make up a keyhole. Of course, if they are inverted, my wife would add. My beloved Six stood behind Five, like... an upturned ram's horn. One, two, three, four, five, six. I can count now. Bye then! Seven stood stiff, like a stork's neck in a very elegant bow tie. Behind her was Eight, hugging

\footnotetext{
3 In Poland (Lublin, Kindergarten no. 49).

4 The full text with illustrations is available on the website: http://olaplocinska.com/wordpress/index. php/2016/02/13/numbers/ (accessed: 15.03.3021).
} 
herself affectionately. Such a cute snowman, made of two snowballs. After Eight, Nine stood calm, she looked like Six upside down. One, two, three, four, five, six, seven, eight, nine. What's next? I don't know. The numbers stood respectfully because they wanted to see themselves on fabulously colorful stamps. And suddenly Zero appeared. She was late, she didn't stop and the line broke. Nine fell over, Eight fell over, numbers grinned and all fell down. The racket was hellish, the numbers broke. Zero stood up slowly by the window and said, "One thing is true, I am a sister number to all of you. I am the most important, so I go first!" And they started arguing and flailing their arms, stomping, scratching, and screaming, "Don't count on it!" One, two, three, four, five, six, seven, eight, nine. And then what? I don't know. "It's a scandal, Zero can't rule us all! This is not fair, we all waited patiently." Ok, let's all agree that from now on there is no zero. Let's ask the postman where to get sixty cents. How to create ten pounds, one hundred, two hundred or a million when Zero is gone, and she was here a moment ago? "I'm leaving you numbers!" said Zero and she wanted to leave the line. The postman took the floor, "As you all know, the view changes depending on where you stand. What is it called? Ah, right, the standpoint! It is clear that without Zero Ten wouldn't stand, but without One in front, it wouldn't stand either! There's one conclusion, as Professor Numberton says, everyone has their place and everyone is needed. Everyone is equal, and whoever respects consent, I will present them with a beautiful stamp as a reward! The numbers all reconciled. They got their stamps, and when they saw them, they were on cloud nine. Why? Because looking at the postage stamps the numbers could all admire... themselves. ${ }^{5}$

After being presented with the content of the story and looking at the illustrations in Numbers (drawn by Aleksandra Woldańska-Płocińska ${ }^{6}$ ), the children were offered various mathematical activities. First, 11 children were selected to act out the story. Willing actors received cards with images of all the numbers. Their task was to play the role of the numbers from 0 to 9 and the postman. The teacher-narrator read the story out loud while the children illustrated its content with their bodies and gestures. Following the plot, the children had to line up in the correct order at the post office window. Then, with their bodies and gestures, every child showed the shape of their number and spoke their lines individually and together. Acting out quarrels and disputes between the numbers was recommended to be done silently, only with facial expressions, which was conducive to transmitting and reading messages and symbolic codes. The following activities were also performed actively and in motion. Among them were:

1. arranging numbers (child actors) in a row,

2. reading a series of numbers (one by one, backwards, every second number),

3. showing numbers with their fingers (what number are you?),

Author's own translation.

${ }^{6}$ http://olaplocinska.com/wordpress/index.php/2016/02/13/numbers/ (accessed: 15.03.3021). 
4. determining the place of a number in the series (e.g., what number is between 4 and 6, list all numbers lower than 9; what numbers go before 8 , what numbers follow 6),

5. how many numbers (children) are between 4 and 9 ? These children step out of the line and call out their number.

Another interesting task inspired by the story was to create new vivid images of large numbers. At the beginning two-digit "live numbers" were created by combining numbers 1-9 and 0. Actors playing numbers from 1 to 9 lined up. The child playing zero was more dynamic. He/she was asked to approach each number in line. When it approached a number, e.g., 1 and stood on its right the children watching the activity would read the number as 10 , etc. It was the viewers' job to read new numbers out loud.

Children were also asked to step out of the line in twos, symbolically hold each other's hands and show by means of cards what numbers can be made from them. For example, the teacher said, "The child who plays the number 3 and the child who plays the number 6 please come on the stage. What number can be made from these two numbers? Read it (36), then switch places. What number can you see now (63)? Then the children-numbers were picked in threes, fours, and more, and they formed new numbers.

The activities with numbers continued: designing postage stamps, role-playing and creating math fairy tales, solving problems with coins and banknotes that children would use to buy stamps, adding and subtracting numbers, looking for a number that is a sum component, or a number that is the result of a math operation. The table shows the activities proposed to children, relating them to Kozak-Czyżewska's framework (2008: 146).

Working with Numbers provided the children with a lot of joy and excitement. The whole group was involved in the proposed activities. The children especially liked role-playing numbers and creating "live numbers." The proposed various forms of activities allowed the teachers to activate the children with different cognitive and emotional needs and different temperaments. There were many methodological proposals inspired by the plot, which meant that the book content was the subject of children's activity for a long time, both in activities guided by the teacher and initiated by the children, i.e., play and physical and artistic activity. 
Table 1. Mathematical activities inspired by Numbers

\begin{tabular}{|c|c|c|c|}
\hline $\begin{array}{l}\text { Nature of } \\
\text { activity }\end{array}$ & $\begin{array}{l}\text { Type of } \\
\text { activity }\end{array}$ & $\begin{array}{c}\text { Material } \\
\text { used }\end{array}$ & Examples and description of the activity \\
\hline \multirow{6}{*}{ imitative } & \multirow{3}{*}{$\begin{array}{l}\text { manipulative } \\
\text { and motor }\end{array}$} & tangible & $\begin{array}{l}\text { - children act out different digits, use their body } \\
\text { to form the shape of a digit } \\
\text { - arranging plastic digit-shaped blocks in order } \\
\text { from } 0 \text { to } 9 / 10\end{array}$ \\
\hline & & graphic & $\begin{array}{l}\text { - arranging cards (pictures or postage stamps) } \\
\text { with images of numbers from } 1 \text { to } 9 \text { or with } \\
\text { a number of dots in a sequence }\end{array}$ \\
\hline & & symbolic & $\begin{array}{l}\text { - recognizing the numbers read out loud by the } \\
\text { teacher, searching for these numbers among } \\
\text { pictures or among digit-shaped blocks } \\
\text { - writing / tracing the shape of numbers on } \\
\text { different materials (e.g., a tray with groats, } \\
\text { a stick in the sand, etc.) }\end{array}$ \\
\hline & \multirow{3}{*}{ verbal } & tangible & $\begin{array}{l}\text { - listing numbers in order from } 1 \text { to } 10 \text { and back } \\
\text { from } 10 \text { to } 1 \text {, searching the room for items that } \\
\text { contain the shape of a number } 1,2,3 \text {, etc. } \\
\text { - using terms related to space: in front of, } \\
\text { behind, between, previous, next, first, last, } \\
\text { every second }\end{array}$ \\
\hline & & graphic & $\begin{array}{l}\text { - choosing from among the graphic diagrams } \\
\text { the one that shows the result of the operation, } \\
\text { e.g., } 4+2\end{array}$ \\
\hline & & symbolic & $\begin{array}{l}\text { - describing what the digit looks like } \\
\text { - assigning coin and banknote symbols (PLN } \\
\text { 1, PLN 2, PLN 5, PLN 10) to numbers or } \\
\text { numbers on stamps and pictures }\end{array}$ \\
\hline
\end{tabular}




\begin{tabular}{|c|c|c|c|}
\hline $\begin{array}{l}\text { Nature of } \\
\text { activity }\end{array}$ & $\begin{array}{l}\text { Type of } \\
\text { activity }\end{array}$ & $\begin{array}{c}\text { Material } \\
\text { used }\end{array}$ & Examples and description of the activity \\
\hline \multirow{7}{*}{ creative } & \multirow{2}{*}{$\begin{array}{l}\text { manipulative } \\
\text { and motor }\end{array}$} & graphic & $\begin{array}{l}\text { - creating live numbers according to children's } \\
\text { own ideas, showing numbers with gestures }\end{array}$ \\
\hline & & symbolic & $\begin{array}{l}\text { - building new two-, three- and multi-digit } \\
\text { numbers out of cards }\end{array}$ \\
\hline & \multirow{3}{*}{ verbal } & tangible & - reading the created numbers out loud \\
\hline & & graphic & $\begin{array}{l}\text { - designing postage stamps with images of } \\
\text { numbers }\end{array}$ \\
\hline & & symbolic & $\begin{array}{l}\text { - formulating the content of tasks for operations, } \\
\text { e.g., } 4+1=5\end{array}$ \\
\hline & \multirow{2}{*}{ cognitive } & tangible & $\begin{array}{l}\text { - discovering mathematical relationships: } \\
\text { the place of numbers in a series, the role of } 0\end{array}$ \\
\hline & & $\begin{array}{l}\text { graphic } \\
\text { symbolic }\end{array}$ & $\begin{array}{l}\text { - designing poems and narratives about digits } \\
\text { and numbers } \\
\text { - illustrating the created booklets }\end{array}$ \\
\hline
\end{tabular}

Source: Author's own materials.

\section{At Our House There Are ${ }^{7}$}

The story At our house is an example of a narrative for children describing reality using mathematics. The narrator describes their family using the language of mathematics, that is, comparing family members and elements describing their family numerically (e.g., body parts, diseases, activities, number of guests). The text of At our house by Isabel Minhós Martins and Madalena Matoso reads:

There are ... 6 heads at our house. Every one of them thinks about their own affairs but sometimes they all think about the same thing. There are 78 fingers, 20 small fingers and 20 stubby fingers in our house. In total, that's 118 nails my mom cuts every Sunday. There are 6 bellies and approximately 40 meters of intestines at our house, both large and small. We stand in line to one bathroom every morning. There are 16 large and small boobs at our house. With the onset of spring, they all catch the sun on the porch. There are 3,560 freckles at our house. There would be a lot fewer if it wasn't for my dad's back... At our house there are 6 noses and 12 nostrils. During the pollen season, we all sneeze in the same direction. There are 1,351 bones at our house that are

https://www.tmc.com.pl/pl/kategorie/40025-at-our-house-9781849760492.html (accessed: 15.03.3021). 
not always in the best shape. Doctor Zalewski said that we have a total of 1 scoliosis, 1 joint degeneration, and 2 discopathies. Besides that, thank you, we're fine. There are 800,000 hairs in our house that need to be washed, dryed, untangled and combed. When summer comes, we go to the hairdressers. There are 6 mouths, 6 tongues and 168 teeth at our house. My grandfather says we beat our gums like magpies, but eat more like dragons. There are 5 pairs of legs, 4 paws and 10 feet at our house. In other words, 10 shoes to take off and 10 socks to throw in the corner in the evening, and sometimes just 2 hands to deal with all that. There are 6 of us at our house, but when we throw a party, suddenly there are 16 of us. The bell rings and there are 27 of us. A few more cousins come and we become 32. Hm... let's count. Well, at home we now have 32 heads, 618 fingers, over 2 kilometers of intestines, 72 boobs (large and small) 32 noses, 60 legs, 8 paws, 6822 bones, over a million hairs and 924 teeth that chew and grind continuously.

The content and form of the book is an example of communicating in mathematical language, and the creative tasks inspired by this publication were aimed at developing the ability to use numbers in everyday life and improve the ability to describe reality using mathematical language.

The book At our house aroused the children's curiosity and sparked their interest in human anatomy. The content and illustrations encouraged the study of the human body, viewing albums, illustrations, and x-rays. After these activities, children were particularly eager to describe their body structure in the language of mathematics and make posters describing their group in terms of quantity. A lot of narratives and mathematical stories were created.

8 Author's own translation. 
Table 2. Mathematical activities inspired by At our house

\begin{tabular}{|c|c|c|c|c|}
\hline $\begin{array}{l}\text { Nature of } \\
\text { activity }\end{array}$ & $\begin{array}{l}\text { Type of } \\
\text { activity }\end{array}$ & $\begin{array}{c}\text { Material } \\
\text { used }\end{array}$ & \multicolumn{2}{|c|}{ Examples and description of the activity } \\
\hline \multirow{7}{*}{ imitative } & \multirow[b]{2}{*}{$\begin{array}{l}\text { manipulative } \\
\text { and motor }\end{array}$} & tangible & \multicolumn{2}{|c|}{$\begin{array}{l}\text { - studying the human body, e.g., counting and } \\
\text { pointing to children's heads, legs, hands, feet, } \\
\text { fingers, nostrils, etc. }\end{array}$} \\
\hline & & $\begin{array}{l}\text { graphic } \\
\text { symbolic }\end{array}$ & \multicolumn{2}{|c|}{$\begin{array}{l}\text { - viewing albums, illustrations, } \mathrm{x} \text {-rays of the } \\
\text { structure of the human body } \\
\text { - arranging the images of the numbers } \\
\text { mentioned in the book, e.g., } 6 \text { heads, } 78,20 \\
\text { etc., using plastic digit-shaped blocks or cards } \\
\text { illustrating the numbers and arranging them in } \\
\text { order from the lowest to the highest number }\end{array}$} \\
\hline & \multirow{5}{*}{ verbal } & $\begin{array}{l}\text { tangible } \\
\text { graphic } \\
\text { symbolic }\end{array}$ & \multicolumn{2}{|c|}{$\begin{array}{l}\text { - finding numbers in the text, recognizing them, } \\
\text { reading them and writing them on one's own }\end{array}$} \\
\hline & & \multirow[t]{3}{*}{ graphic } & \multicolumn{2}{|c|}{$\begin{array}{l}\text { - using dashes to write the number of units, } \\
\text { tens, hundreds, and thousands of a given } \\
\text { number mentioned in the text, e.g., } 78 \\
\text { fingers, etc. depending on children's needs and } \\
\text { competencies }\end{array}$} \\
\hline & & & tens & units \\
\hline & & & IIIIIII & IIIIIIII \\
\hline & & symbolic & \multicolumn{2}{|c|}{$\begin{array}{l}\text { - symbolic drawing of body parts and other } \\
\text { things mentioned in the narrative (head, } \\
\text { fingers, small fingers, stubby fingers, nails, etc.) } \\
\text { and matching them to numbers on the cards } \\
(6,78,20,118 \text {, etc.) Guessing how many body } \\
\text { parts there were: what symbol it is and what } \\
\text { number matches it }\end{array}$} \\
\hline
\end{tabular}




\begin{tabular}{|c|c|c|c|}
\hline $\begin{array}{l}\text { Nature of } \\
\text { activity }\end{array}$ & $\begin{array}{l}\text { Type of } \\
\text { activity }\end{array}$ & $\begin{array}{c}\text { Material } \\
\text { used }\end{array}$ & Examples and description of the activity \\
\hline \multirow[b]{3}{*}{ creative } & $\begin{array}{l}\text { manipulative } \\
\text { and motor }\end{array}$ & $\begin{array}{l}\text { tangible } \\
\text { graphic } \\
\text { symbolic }\end{array}$ & $\begin{array}{l}\text { - drawing or creating an anatomical model of } \\
\text { the human body, putting sticky notes with } \\
\text { a coded number specifying e.g., the number of } \\
\text { heads in a selected group e.g., in the family or } \\
\text { in a group of friends }\end{array}$ \\
\hline & verbal & $\begin{array}{l}\text { tangible } \\
\text { graphic } \\
\text { symbolic }\end{array}$ & $\begin{array}{l}\text { - creating a similar narrative, poster, illustration, } \\
\text { e.g. "In our group, there are...," "in our family, } \\
\text { there are..." }\end{array}$ \\
\hline & cognitive & $\begin{array}{l}\text { tangible } \\
\text { graphic } \\
\text { symbolic }\end{array}$ & $\begin{array}{l}\text { a) solving problems based on the narrative: } \\
\text { - If there are } 6 \text { family members and suddenly } \\
\text { there are } 16 \text { of them, what do you think } \\
\text { happened. Who visited the family, how many } \\
\text { people/animals. Draw or suggest a solution. } \\
\text { - Who can } 32 \text { heads belong to? How many } \\
\text { hands do they have? Legs? Design a solution. } \\
\text { Draw. Create a schema based on the plot. } \\
\text { - How many noses have } 12 \text { nostrils? } \\
\text { - Who can } 60 \text { legs belong to? If it were people. } \\
\text { What if they were animals? } \\
\text { - We have } 618 \text { fingers. How many hands are } \\
\text { there? } \\
\text { - Can you count hairs? } 1,000,000 \text { hairs, how } \\
\text { many are these? } \\
\text { b) solving similar tasks, e.g., how many fingers do } \\
2 \text { pairs of gloves have? Etc. } \\
\text { c) creating new tasks by children for their } \\
\text { mathematical narratives }\end{array}$ \\
\hline
\end{tabular}

Source: Author's own materials.

\section{Results and Conclusion}

The aim of the study was to show that books with mathematical content in the form of narrative poetry or mathematical fairy tales may be used to create educational situations to inspire mathematical activity, both imitative and creative.

Research shows that children's literature used as an educational tool affects many spheres of child development. The appearance of beautifully illustrated picture books with mathematical content creates new opportunities for using children's literature in education. The conducted analysis suggests that mathematical books and rhymed mathematical texts provide children with a lot of joy, not only in terms of learning 
new content, but also the possibility of experiencing the content multiple times in various types of expression. Stories with mathematical content affect not only the cognitive sphere but also the emotional, social and moral sphere. By providing positive experiences, they support the learning processes, awaken children's motivation and the joy of discovering mathematical patterns.

The possibilities of stimulating mathematical activity presented above, both imitative (closed tasks) and creative (open tasks such as drama or drawing), inspired by a mathematical plot, are a means of gathering new mathematical experiences. Such activities and the accompanying experiences allow children not only to consolidate their knowledge but also to acquire and improve mathematical skills. They spark curiosity and interest in mathematics, which allows them to build new knowledge. Due to the specificity of the texts used in the study, this knowledge relates mainly to the concept of the numbers, built in relation to many of its aspects (cardinal, ordinal, code, arithmetic, and its contractual value) and efficiency related to counting. Contact with the literature with mathematical content can also be a way to improve existing mathematical skills and abilities (e.g., converting, counting in tens, hundreds, and coding information). A mathematical book triggers new activities supporting mathematical education, e.g., artistic and construction activities. In that way, children may develop mathematical interests, perceptive skills, attention, memory, learn symbolization, develop imagination and enrich mathematical language. Contact with a picture book encourages to mathematize reality and look at the world with "mathematical eyes." Introducing poetry and mathematical narratives into preschool education appropriately to the children's age, cognitive, and emotional needs can also be a new diagnostic space where the researcher carefully looks at the impact of literature or even consciously tests this impact on child development.

The use of picture books with mathematical content in preschool education is currently perceived as an experimental activity, also because there is not enough research on its effectiveness in early mathematical education. Nevertheless, it has been shown that mathematical books have a great educational potential for being the basis of multifaceted and expressive mathematical activities for children. Both the content of the mathematical books and their form allow the teacher to create interesting and varied mathematical activities with the active involvement of the group. The described activities may encourage a deliberate search and creation of teachers' own repertoire of valuable books, narratives, and poems. Teachers looking for mathematically saturated texts for their methodological experiments can make teaching and learning more interesting and individualized. Reviewing and working with mathematical stories also brings to mind the idea of encouraging children to create and illustrate their own texts, then act them out, and design new tasks for their colleagues. 
Picture books and counting books should be available to every preschooler and pupil and every teacher should have a series of mathematical books helpful in the educational process. The teacher may select texts from native or foreign poetry on purpose in order to organize new mathematical activities, both imitative and creative. Therefore, it is worth using picture books with mathematical plots and narrative poetry to a greater extent in early education.

\section{Bibliography}

Arizpe E., Styles M. (2003). Children reading pictures. Interpreting visual text, London: Routledge/Falmer.

Casey B.M., Andrews N., Schindler H., Kersh J.E. Samper A., Copley J. (2008). The development of spatial skills through interventions involving block building activities, "Cognition and Instruction”, vol. 26, no. 3, pp. 269-309. DOI: 1080/07370000802177177.

Casey B.M., Paugt P., Ballard N. (2002). Sneeze builds a castle, Chicago: Wright Group Literacy/McGraw-Hill.

Cheng Y.-L., Mix K.S. (2014). Spatial training improvements children's mathematics Ability, "Journal of Cognition and Development", vol. 15, no. 1, pp. 2-11. DOI: 10.1080/15248372.2012.725186.

Cygan J. (2011), Cyferki, Kraków: Wydawnictwo Czerwony Konik.

Darien J. (2012) The war of the numbers, Torun: Wydawnictwo Tako.

Dolya G. (2007). Technologia rozwoju dziecka. Klucz do uczenia się: podejście Wygotskiego do wczesnego rozwoju dziecka, Gdańsk: Transfer Learning Solutions.

Filip J., Rams T. (2000). Dziecko w świecie matematyki, Kraków: Oficyna Wydawnicza "Impuls".

Gruszczyk-Kolczyńska E. (1997). Dzieci ze specyficznymi trudnościami w uczeniu się matematyki, Warszawa: Wydawnictwa Szkolne i Pedagogiczne.

Hong H. (1996). Effects of mathematical learning through children's literature on math achievement and dispositional outcomes, "Early Childhood Research Quarterly", vol. 11, no. 4, pp. 477-494. DOI: 10.1016/S0885-2006(96)90018-6.

Jennings C.M., Jennings J.E., Richey J., Dixon-Krauss L.D. (1992). Increasing interest and achievement in mathematics through children's literature, "Early Childhood Research Quarterly”, vol. 7, no. 2, pp. 263-276. DOI: 10.1016/0885-2006(92)90008-M.

Kozak-Czyżewska E. (2008). Formy aktywności matematycznej uczniów klas początkowych, [in:] S. Guz, T. Sokołowska-Dzioba, A. Pielecki (eds.), Wielowymiarowość aktywności i aktywizacji, Warszawa: Wyższa Szkoła Pedagogiczna TWP, pp. 139-151.

Minhós Martins I., Matoso M. (2012). At our house, Warszawa: Grafton.

Ross C., Dryden G. (2009). Zabawy fundamentalne 2. Gry i zabawy rozwijające zdolności matematyczne. Od 2 do 6 roku, Gdańsk: Transfer Learning Solutions.

Rostek I. (2019). Narratives in STEM education, "Edukacja Elementarna w Teorii i Praktyce, vol. 14, no. (4)54, pp. 39-48. DOI: 10.35765/eetp.2019.1454.03.

Strelau J. (1992). Temperament i inteligencja, Warszawa: Wydawnictwo Naukowe PWN. 
Treliński G. (2005). Stymulowanie aktywności - przeciwdziatanie bezradności matematycznej ucznia, [in:] Z. Ratajek (ed.), Uczeń we wspótczesnej szkole. Problemy reformy edukacji wczesnoszkolnej, Kielce: Wydawnictwo Akademii Świętokrzyskiej, pp. 47-59.

Van den Heuvel-Panhuizen M., Van den Boogard S. (2008). Picture books as an impetus for kindergardens' mathematical thinking, "Mathematical Thinking and Learning", vol. 10, no. 4, pp. 341-373. DOI: 10.1080/10986060802425539.

Van den Heuvel-Panhuizen M., Elia I., Robitzsch A. (2015). Kindergarten's performance in two types of imaginary perspective-talking, "ZDM Mathematics Education", vol. 47, no. 3, pp. 345-362. DOI: 10.1007/s11858-015-0677-4.

Van den Heuvel-Panhuizen M., Elia I., Robitzsch A. (2016). Effects of reading picture books on kindergartners' mathematic performance, "Educational Psychology", vol. 36, no. 2, pp. 323-346. DOI: 10.1080/01443410.2014.963029.

Young-Loveridge J.M. (2004). Effects on early numeracy of a program using number books and games, "Early Childhood Research Quarterly", vol. 19, no. 1, pp. 82-98. DOI: 10.1016/j.ecresq.2004.01.001.

\section{Netography}

http://olaplocinska.com/wordpress/index.php/2016/02/13/numbers/ (accessed: 15.03.3021). https://p118.przedszkola.net.pl/aktualnosci/konkurs-matematyka-w-wierszykach.html (accessed: 15.03.3021).

https://psloneczko.szkolnastrona.pl/art,3038,4-wierszyki-matematyczne (accessed: 15.03.3021). https://www.tmc.com.pl/pl/kategorie/40025-at-our-house-9781849760492.html (accessed: 15.03.3021)

https://www.tmc.com.pl/pl/kategorie/40025-at-our-house-9781849760492.html (accessed: 15.03.3021).

\section{ADDRESS FOR CORRESPONDENCE}

Barbara Bilewicz-Kuźnia

Maria Curie-Skłodowska University in Lublin e-mail: barbara.bilewicz@poczta.umcs.lublin.pl 